Article

\title{
Evaluation of Ion-Exchange Characteristics of Cesium in Natural Japanese Rocks
}

\author{
Takuya Miura ${ }^{1, *}$, Atsushi Sasaki ${ }^{2}$ and Masatoshi Endo ${ }^{1}$ \\ 1 Graduate School of Science and Engineering, Yamagata University, 4-3-16 Jonan, Yonezawa, \\ Yamagata 992-8510, Japan; endomasa@yz.yamagata-u.ac.jp \\ 2 Faculty of Engineering, Yamagata University, 4-3-16 Jonan, Yonezawa, Yamagata 992-8510, Japan; \\ atsushi@yz.yamagata-u.ac.jp \\ * Correspondence: t.miura1230@gmail.com; Tel.: +81-238-26-3142
}

Received: 20 June 2018; Accepted: 10 August 2018; Published: 17 August 2018

\begin{abstract}
A large amount of soil was contaminated by radioactive cesium due to the accident at the Fukushima Daiichi Nuclear Power Plant in Japan in 2011. The adsorption behavior of cesium ions $\left(\mathrm{Cs}^{+}\right)$is strongly influenced by numerous factors, including the components, structure and weathering conditions of natural soil. The adsorption and ion exchange characteristics of $\mathrm{Cs}^{+}$ions onto and from natural Japanese rocks with well-known components were studied. $\mathrm{Cs}^{+}$adsorption onto volcanic rocks $(0.9-5.3 \mathrm{mg} / \mathrm{g})$ occurred more easily than that onto plutonic rocks $(0.7-0.8 \mathrm{mg} / \mathrm{g})$ due to differences in crystallinity. In addition, the adsorption quantity of cesium increased with increasing lattice water content and content of ion-exchangeable cations in the rock samples. The cesium adsorption ability of rock was inhibited by seawater and coexisting ions in the solution. Cesium adsorption quantities onto andosol, containing the corrosion products, increased approximately 2.7 -fold with increasing $\mathrm{pH}$ from neutral to basic. Cesium desorption differed depending on the type of salt used, and the desorption rates were highest with ammonium salts. $\mathrm{Cs}^{+}$desorption from regions such as the soil interlayer and the pores were inhibited by melting of the rock surface.
\end{abstract}

Keywords: cesium; natural Japanese rocks; adsorption/desorption; heat treatment

\section{Introduction}

The accident at the Fukushima Daiichi Nuclear Power Plant, which occurred as a consequence of the Great East Japan Earthquake on March 11, 2011, resulted in widespread contamination with radioactive materials [1-3]. A large amount of soil was contaminated by this accident. However, efficient and practical remediation of contamination caused by radioactive substances is difficult. Several reports have examined cesium adsorption/desorption onto zeolite, bentonite, and mica [4-12]. The adsorption processes of exchangeable cations on the adsorption site of their minerals are different. For example, cesium ions $\left(\mathrm{Cs}^{+}\right)$are adsorbed in the interlayer of lamellar minerals and in the pores of zeolite $[8,11,12]$. However, the mechanism by which $\mathrm{Cs}^{+}$adsorb onto and desorb from all minerals on the earth has not been fully elucidated. Natural soil is mixed with various kinds of rock $[1,4,13]$. Additionally, weathering processes, such as erosion, cause structural and chemical changes in natural minerals. The radioactive materials from the Fukushima Daiichi Nuclear Power Plant have been incorporated into clay minerals - such as mica-in the natural soil in the surrounding environment. $\mathrm{Cs}^{+}$ions are known to adsorb strongly onto the natural soil, such as biotite $[7,14,15]$. In particular, the half-time of Cs-137 is about 30 years $[7,10]$. Therefore, quick response to soil contamination is necessary.

Since the adsorption and desorption of $\mathrm{Cs}^{+}$ions onto and from natural soil are strongly influenced by several factors, including the components, structure, and weathering conditions of the soil, the behavior on Cs in an actual environment has not yet been determined. The clear elucidation of the 
cesium adsorption and desorption mechanism is necessary. Therefore, in this study, the adsorption and ion exchange characteristics of $\mathrm{Cs}^{+}$ions onto and from natural Japanese rocks with well-known components were studied.

\section{Materials and Methods}

\subsection{Natural Japanese Rocks}

Natural Japanese rocks were obtained from the Geological Survey of Japan in National Institute of Advanced Industrial Science and Technology (AIST). These natural Japanese rocks were ground into powder in a mortar and sieved with $0.149 \mathrm{~mm}$ sieves. Basic data, such as the sample components and collection locations, were previously reported [16]. Figure 1 shows that the reference samples were classified as igneous rock, sedimentary rock, metamorphic rock, and sediments. In this study, andesite (JA), basalt (JB), granodiorite (JG), gabbro (JGb), chert (JCh), slate (JSl), andosol (JSO), and stream sediment (JSd) were selected. "J" in these abbreviations denotes that these samples were collected in Japan. The silica oxide $\left(\mathrm{SiO}_{2}\right)$ content and crystallinity of rock strongly influence $\mathrm{Cs}^{+}$adsorption behavior. Igneous rock and the other rock groups were further divided into two categories: before weathering and after weathering.

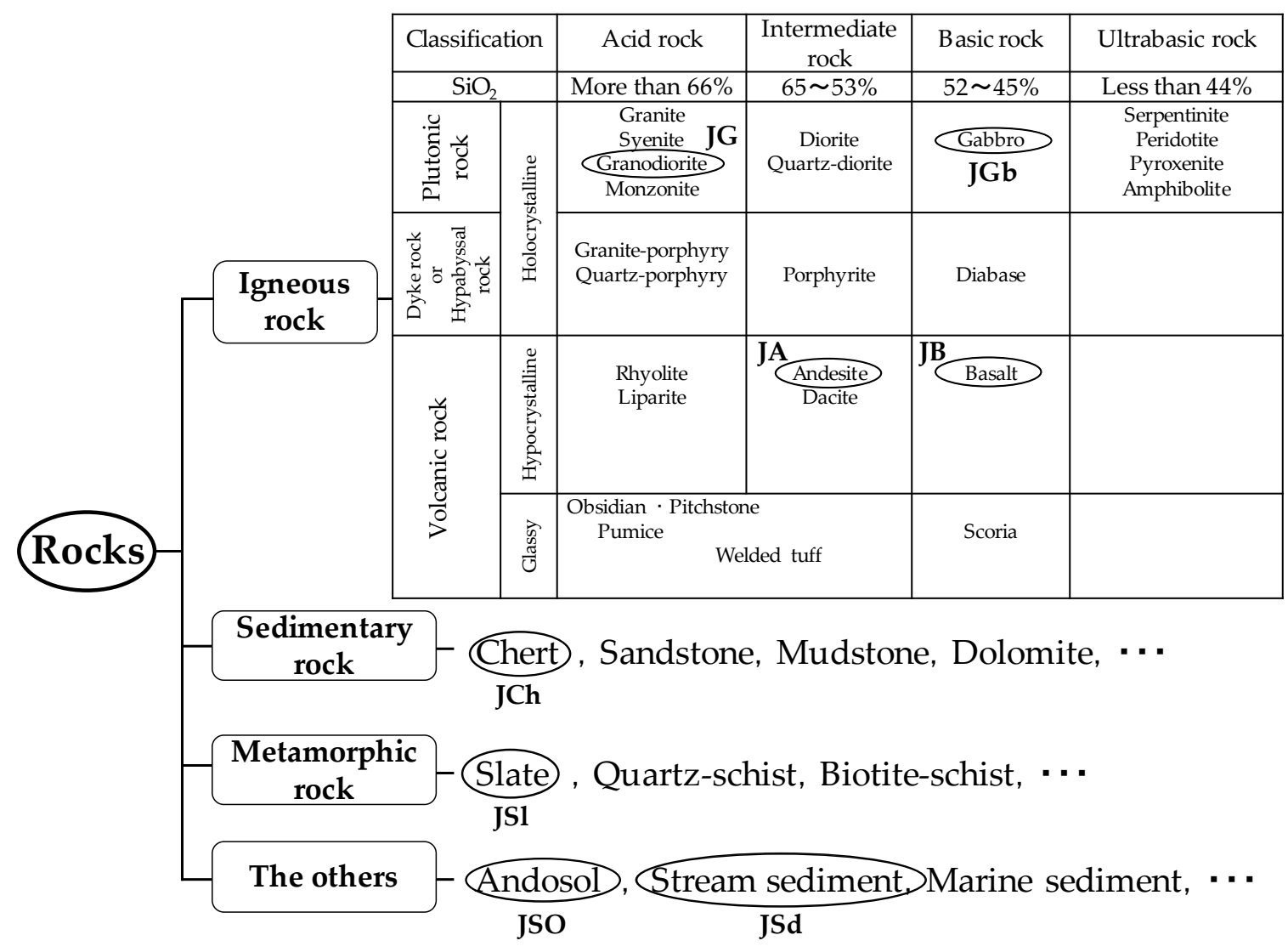

\section{JA, JB, JG, JGb, JCh, JS1, JSO and JSd were shown as andesite, basalt, granodiorite, gabbro, chert, slate, andosol and stream sediment.}

Figure 1. Classification of rocks used in this study: igneous rock (JA, JB, JG, and JGb), sedimentary rock (JCh), metamorphic rock (JSl), and other rocks (JSO and JSd). 


\subsection{Cesium Adsorption Experiments}

$\mathrm{Cs}^{+}$aqueous solutions of 200 or $2000 \mathrm{mg} / \mathrm{L}$ were prepared from dissolving cesium chloride powder (Wako Pure Chemical Industries, Ltd., Osaka, Japan, Assay min. 99.0\%) into deionized water. The particle diameter of all the mineral samples was less than $0.149 \mathrm{~mm}$. The $\mathrm{Cs}^{+}$adsorption saturation time of the minerals in this study was $5 \mathrm{~min}$ for zeolites and $30 \mathrm{~min}$ for the other minerals. $\mathrm{A} \mathrm{Cs}^{+}$ solution of $50 \mathrm{~mL}$ and a mineral sample of $0.5 \mathrm{~g}$ were placed in a $200 \mathrm{~mL}$ polystyrene container and stirred for $2 \mathrm{~h}$. Each sample solution was filtered through a $0.20-\mu \mathrm{m}$ syringe filter, and the saturation quantities of adsorbed $\mathrm{Cs}^{+}$were determined on the basis of the $\mathrm{Cs}^{+}$concentration in the filtrates, as measured by inductively coupled plasma-mass spectrometry (ICP-MS, ELAN-DRCII, Perkin Elmer, Yokohama, Japan).

The adsorption tests with seawater were carried out using the commercial product Tetra Marin ${ }^{\circledR}$ Salt Pro sea salt (Spectrum Brands Japan Co., Ltd., Yokohama, Japan). Cs ${ }^{+}$was added at a concentration of $200 \mathrm{ppm}$ to seawater adjusted to a predetermined concentration (specific gravity 1.020-1.023, $1 \mathrm{~L}$ water, and $33 \mathrm{~g}$ sea salt). $\mathrm{Cs}^{+}$adsorption experiments on $0.5 \mathrm{~g}$ of the rocks were conducted with seawater using the procedure described in the cesium adsorption test using deionized water.

Solutions with coexisting ions, including potassium ions $\left(\mathrm{K}^{+}\right)$, magnesium ions $\left(\mathrm{Mg}^{2+}\right)$, calcium ions $\left(\mathrm{Ca}^{2+}\right)$, and barium ions $\left(\mathrm{Ba}^{2+}\right)$, with concentrations of 100 or $200 \mathrm{ppm}$, were prepared from potassium chloride, magnesium nitrate, calcium carbonate, and barium nitrate, respectively. The initial concentration of $\mathrm{Cs}^{+}$used in these adsorption tests was $200 \mathrm{ppm} . \mathrm{Cs}^{+}$adsorption experiments on $0.5 \mathrm{~g}$ of JB-1a and JSO-1 using solutions with coexisting ions were conducted using the procedure described in the cesium adsorption test, using deionized water.

The $\mathrm{pH}$ of the $\mathrm{Cs}^{+}$solution (200 ppm) was adjusted to 2, 4, 6, 8, 10, and 12 with hydrochloric acid or sodium hydroxide solution. Cesium adsorption experiments were conducted on JB-1a and JSO-1 $(0.5 \mathrm{~g})$ under various $\mathrm{pH}$ conditions using the procedure described in the cesium adsorption test using deionized water.

\subsection{Cesium Desorption Experiments}

Hydrochloric acid $(\mathrm{HCl})$, diammonium hydrogen phosphate $\left(\left(\mathrm{NH}_{4}\right)_{2} \mathrm{HPO}_{4}\right)$, ammonium chloride $\left(\mathrm{NH}_{4} \mathrm{Cl}\right)$, ammonium fluoride $\left(\mathrm{NH}_{4} \mathrm{~F}\right)$, ammonium oxalate $\left(\left(\mathrm{NH}_{4}\right)_{2} \mathrm{C}_{2} \mathrm{O}_{4}\right)$, and ethylenediaminetetraacetic acid disodium salt dihydrate (EDTA-2Na $2 \mathrm{H}_{2} \mathrm{O}$ ) were used in the desorption tests. First, $50 \mathrm{~mL}$ of $0.1 \mathrm{~mol} / \mathrm{L}$ solution of each reagent was added to a JB-1a sample with $\mathrm{Cs}^{+}$adsorbed at $2.01-2.94 \mathrm{mg} / 0.5 \mathrm{~g}$, and the resultant solution was stirred for $2 \mathrm{~h}$. Similar desorption tests were carried out after the adsorption tests.

Solutions with coexisting ions $\mathrm{K}^{+}, \mathrm{Mg}^{2+}, \mathrm{Ca}^{2+}$ and $\mathrm{Ba}^{2+}$ were prepared from potassium chloride, magnesium nitrate, calcium carbonate, and barium nitrate, respectively. Next, $50 \mathrm{~mL}$ of a solution with $200 \mathrm{ppm}$ of each ion was added to JB-1a and JSO- 1 samples with $\mathrm{Cs}^{+}$adsorbed at $1.9-2.5 \mathrm{mg} / 0.5 \mathrm{~g}$ and 2.5-2.7 mg/0.5 g, respectively. The resultant mixtures were stirred for $2 \mathrm{~h} . \mathrm{Cs}^{+}$desorption experiments on $0.5 \mathrm{~g}$ of JB- $1 \mathrm{a}$ and JSO- 1 in the presence of the coexisting ions were conducted using the procedure described in cesium desorption test with ammonium salts.

\subsection{Heat Treatment Experiments}

The rock samples were calcined at $400,600,800$, and $1000{ }^{\circ} \mathrm{C}$, and $\mathrm{Cs}^{+}$adsorption experiments were conducted with the calcined samples. In addition, a desorption experiment using $0.1 \mathrm{~mol} / \mathrm{L}$ hydrochloric acid on the calcined rock samples was carried out. The rock and solution ratios and the procedure after stirring were similar to those used in the adsorption experiments.

Calcined rocks were analyzed by X-ray diffraction (XRD, Ultima-IV, Rigaku, akishima, Japan), thermogravimetric and differential analysis (TG-DTA, 2000 SA, Bruker-AXS, Yokohama, Japan), and scanning electron microscopy (SEM, SU 8000, Hitachi, Minato, Japan). 


\section{Results and Discussion}

\subsection{Adsorption of $\mathrm{Cs}^{+}$onto Natural Japanese Rocks}

The components and crystallinity of natural minerals differ based on the formation process of the mineral with ground heat and pressure [16]. The results of the $\mathrm{Cs}^{+}$adsorption tests indicate that $\mathrm{Cs}^{+}$was adsorbed onto the JA and JB group rocks (volcanic rock: merocrystalline). In contrast, $\mathrm{Cs}^{+}$was hardly adsorbed onto JG and JGb (plutonic rocks: holocrystalline). The adsorption quantities for $\mathrm{Cs}^{+}$onto plutonic rocks, which are highly crystalline, were substantially lower than the adsorption quantities onto the JA and JB groups, which are poorly crystalline (Table 1 and Figure 2). Additionally, the high cesium adsorption ability of JSO was due to the corrosion product on the surface of JSO [1]. Cesium was adsorbed onto the adsorption sites on JSO and the surface hydroxyl groups of the corrosion product.

Table 1. The major constituent of natural Japanese rocks.

\begin{tabular}{ccccccccccccc}
\hline Constituent & JA-1 & JA-3 & JB-1 & JB-1a & JB-2 & JB-3 & JG-1 & JGb-1 & JS1-1 & JCh-1 & JSd-2 & JSO-1 \\
\hline $\mathrm{SiO}_{2}(\%)$ & 64.0 & 62.3 & 52.4 & 52.4 & 53.3 & 51.0 & 72.3 & 43.7 & 59.5 & 97.8 & 60.8 & 38.4 \\
$\mathrm{Al}_{2} \mathrm{O}_{3}(\%)$ & 15.2 & 15.6 & 14.5 & 14.5 & 14.6 & 17.2 & 14.2 & 17.5 & 17.6 & 0.734 & 12.3 & 18.1 \\
$\mathrm{Fe}_{2} \mathrm{O}_{3}(\%)$ & 2.59 & 1.15 & 2.33 & 2.55 & 3.33 & 3.20 & 0.380 & 4.79 & 1.88 & 0.272 & 4.55 & 8.58 \\
$\mathrm{FeO}(\%)$ & 3.98 & 4.83 & 5.99 & 5.78 & 9.98 & 7.85 & 1.61 & 9.43 & 4.52 & 0.087 & 5.96 & 2.52 \\
$\mathrm{MgO}(\%)$ & 1.57 & 3.72 & 7.71 & 7.83 & 4.62 & 5.19 & 0.740 & 7.85 & 2.41 & 0.075 & 2.73 & 2.11 \\
$\mathrm{CaO}(\%)$ & 5.70 & 6.24 & 9.25 & 9.31 & 9.82 & 9.79 & 2.20 & 11.9 & 1.48 & 0.045 & 3.66 & 2.55 \\
$\mathrm{Na}_{2} \mathrm{O}(\%)$ & 3.84 & 3.19 & 2.77 & 2.73 & 2.04 & 2.73 & 3.38 & 1.20 & 2.18 & 0.031 & 2.44 & 0.670 \\
$\mathrm{~K}_{2} \mathrm{O}(\%)$ & 14.2 & 1.41 & 1.43 & 1.40 & 0.420 & 0.780 & 3.98 & 0.240 & 2.85 & 0.221 & 1.15 & 0.340 \\
$\mathrm{H}_{2} \mathrm{O}^{+}(\%)$ & 0.720 & 0.200 & 1.02 & 0.920 & 0.250 & 0.180 & 0.540 & 1.28 & 3.92 & 0.360 & 2.55 & 7.88 \\
$\mathrm{H}_{2} \mathrm{O}^{-}(\%)$ & 0.300 & 0.110 & 0.950 & 0.920 & 0.130 & 0.070 & 0.070 & 0.130 & 0.654 & 0.152 & 0.451 & - \\
\hline
\end{tabular}

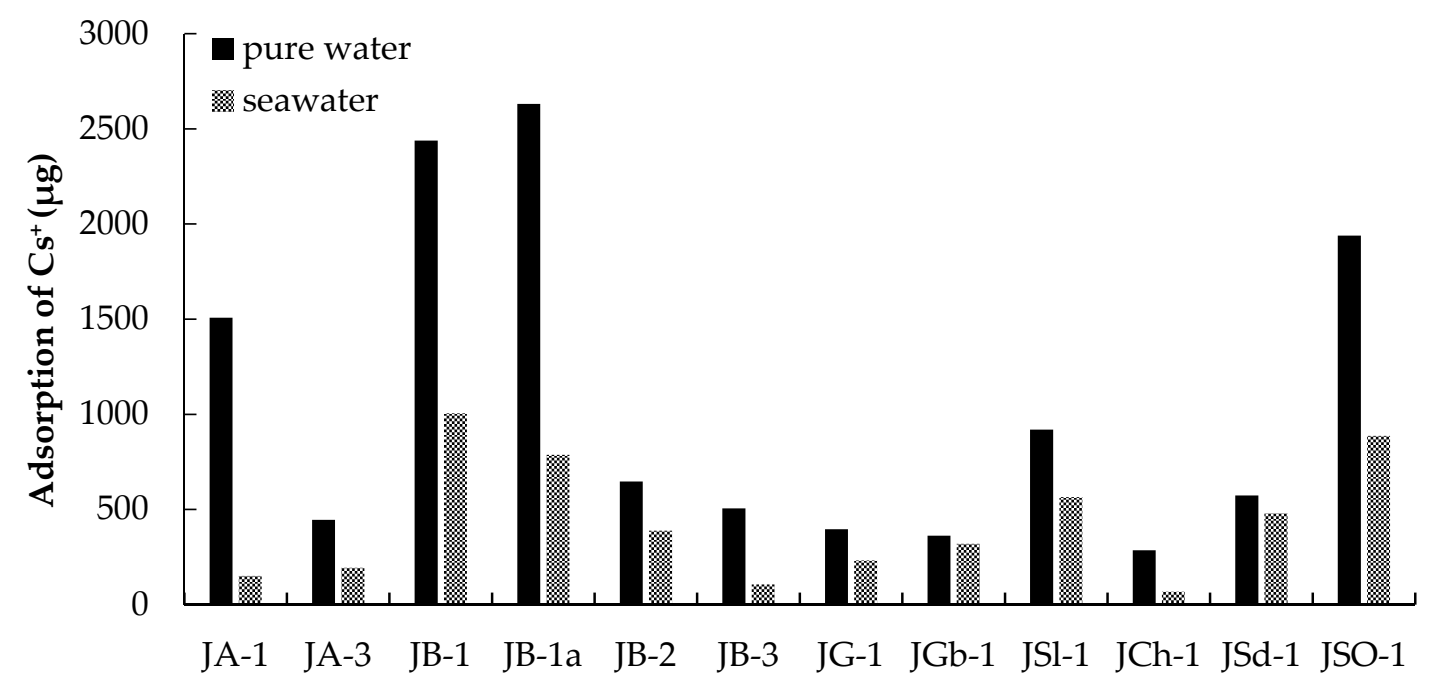

Figure 2. Adsorption quantity of $\mathrm{Cs}^{+}$onto the natural Japanese rocks ( $\left.0.5 \mathrm{~g}\right)$ with pure water or seawater. Initial $\mathrm{Cs}^{+}$concentration: $200 \mathrm{mg} / \mathrm{L}$.

Water components in natural minerals are divided into $\mathrm{H}_{2} \mathrm{O}^{+}$(water in the crystal lattice) and $\mathrm{H}_{2} \mathrm{O}^{-}$(moisture content) [17]. The adsorption quantity of $\mathrm{Cs}^{+}$onto JA and JB groups differed with the collection location and the $\mathrm{H}_{2} \mathrm{O}^{+}$content [16]. The evaporation temperature of $\mathrm{H}_{2} \mathrm{O}^{-}$and $\mathrm{H}_{2} \mathrm{O}^{+}$range from room temperature to $105^{\circ} \mathrm{C}$ and 105 to $950{ }^{\circ} \mathrm{C}$, respectively [17]. Exchangeable cations are held between $\mathrm{H}_{2} \mathrm{O}^{+}$and $\mathrm{H}_{2} \mathrm{O}^{+}$in the soil layers. Therefore, the number of exchangeable cations increases with increasing $\mathrm{H}_{2} \mathrm{O}^{+}$content in the rocks.

Figure 3 shows the variation in the ratio between the adsorbed quantity of $\mathrm{Cs}^{+}$and the $\mathrm{H}_{2} \mathrm{O}^{+}$ content in the rock samples. The $\mathrm{H}_{2} \mathrm{O}^{+}$content in the rock samples was proportional to the adsorbed quantity of $\mathrm{Cs}^{+}$ions. However, the slopes of the two straight approximation lines differed according 
to the weathering condition of the rocks. This relationship is influenced by the leaching of cations as rocks weather in the natural environment [18]. In addition, Table 1 shows that the cation content ratios of $\mathrm{Mg}^{2+}, \mathrm{Ca}^{2+}, \mathrm{Na}^{+}$, and $\mathrm{K}^{+}$in the igneous rocks were relatively lower than those in the other rock groups, such as JSl, JCh, JSd, and JSO. Those cations elute from rock as weathering progresses. Therefore, cesium adsorption quantity for weathered rocks were higher than for the unweathered rocks.

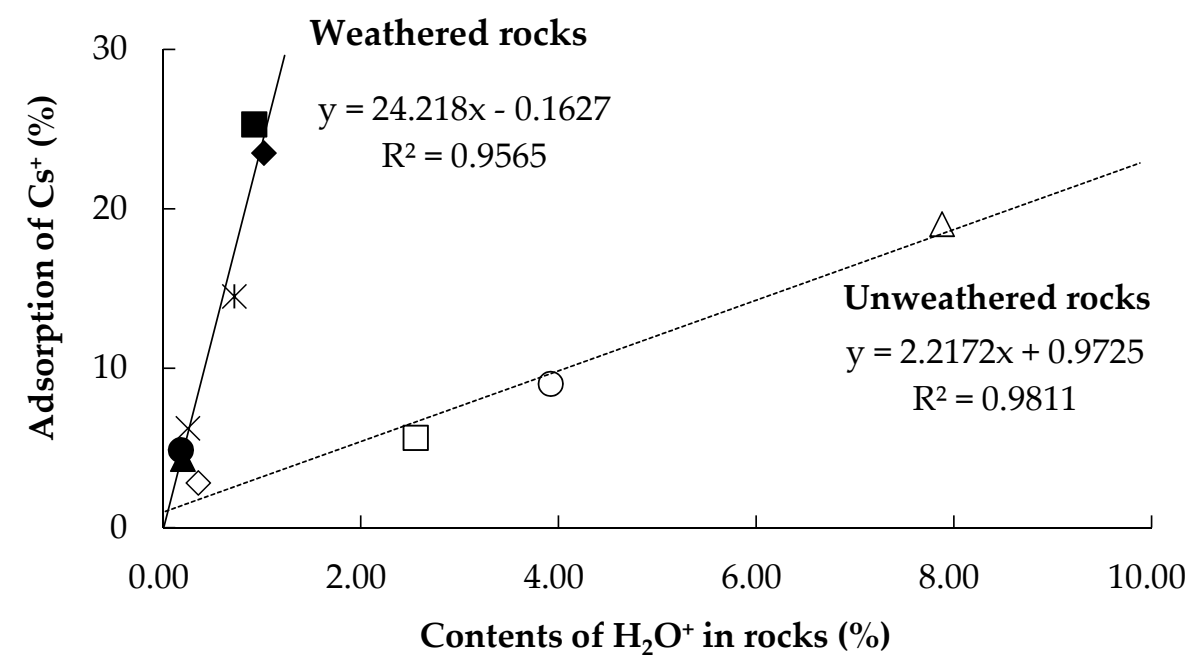

Figure 3. The correlation between the adsorption quantity for $\mathrm{Cs}^{+}$onto the natural Japanese rocks and the $\mathrm{H}_{2} \mathrm{O}^{+}$of the samples. The solid and broken lines reveal the results for unweathered (igneous rocks) and weathered (others) rocks, respectively.

\subsection{Adsorption Behavior of $\mathrm{Cs}^{+}$with Seawater}

Figure 2 shows that the $\mathrm{Cs}^{+}$adsorption quantities on all rock samples were lower when the adsorption was carried out in seawater than when the adsorption was carried out in pure water. The decrease in adsorption quantity for $\mathrm{Cs}^{+}$onto JB-1, JB-1a, and JSO-1, which have large saturated adsorption quantities and high exchangeable cation content, exceeded approximately $50 \%$. The influence of seawater on the $\mathrm{Cs}^{+}$adsorption quantities varied with the type of rock, and the decrease in the $\mathrm{Cs}^{+}$adsorption quantities ranged from $12 \%$ (minimum: JGb-1) to $90 \%$ (maximum: JA-1). Seawater contains high concentrations of cations, such as $\mathrm{Na}^{+}, \mathrm{K}^{+}, \mathrm{Ca}^{2+}$, and $\mathrm{Mg}^{2+}$ [19]. The adsorption of $\mathrm{Cs}^{+}$was inhibited by these cations. Based on these results, cesium adsorption in seawater was more difficult than in pure water.

\subsection{Adsorption of $\mathrm{Cs}^{+}$with Coexisting Ions}

The adsorption quantity of $\mathrm{Cs}^{+}$onto JB-1a was low when divalent ions coexisted. In addition, the $\mathrm{Cs}^{+}$adsorption quantity decreased with increasing concentration of divalent ions (Figure 4). The surfaces of rocks are negatively charged by isomorphous replacement [20-22]. The adsorption affinity associated with the adsorption of divalent ions onto rock is higher than that associated with the adsorption of monovalent ions. Therefore, the observed inhibition of $\mathrm{Cs}^{+}$adsorption onto rock increased in the sequence $\mathrm{K}^{+}<\mathrm{Ba}^{2+} \approx \mathrm{Mg}^{2+}<\mathrm{Ca}^{2+}$.

In contrast, $\mathrm{Cs}^{+}$adsorption onto JSO-1 was more affected by the concentration of coexisting ions than by their valence. $\mathrm{Cs}^{+}$adsorption characteristics of JB-1a and JSO-1 differed according to the cation type and concentration. $\mathrm{Cs}^{+}$adsorption in both JB-1a and JSO-1 was inhibited most effectively by $\mathrm{Ca}^{2+}$. 


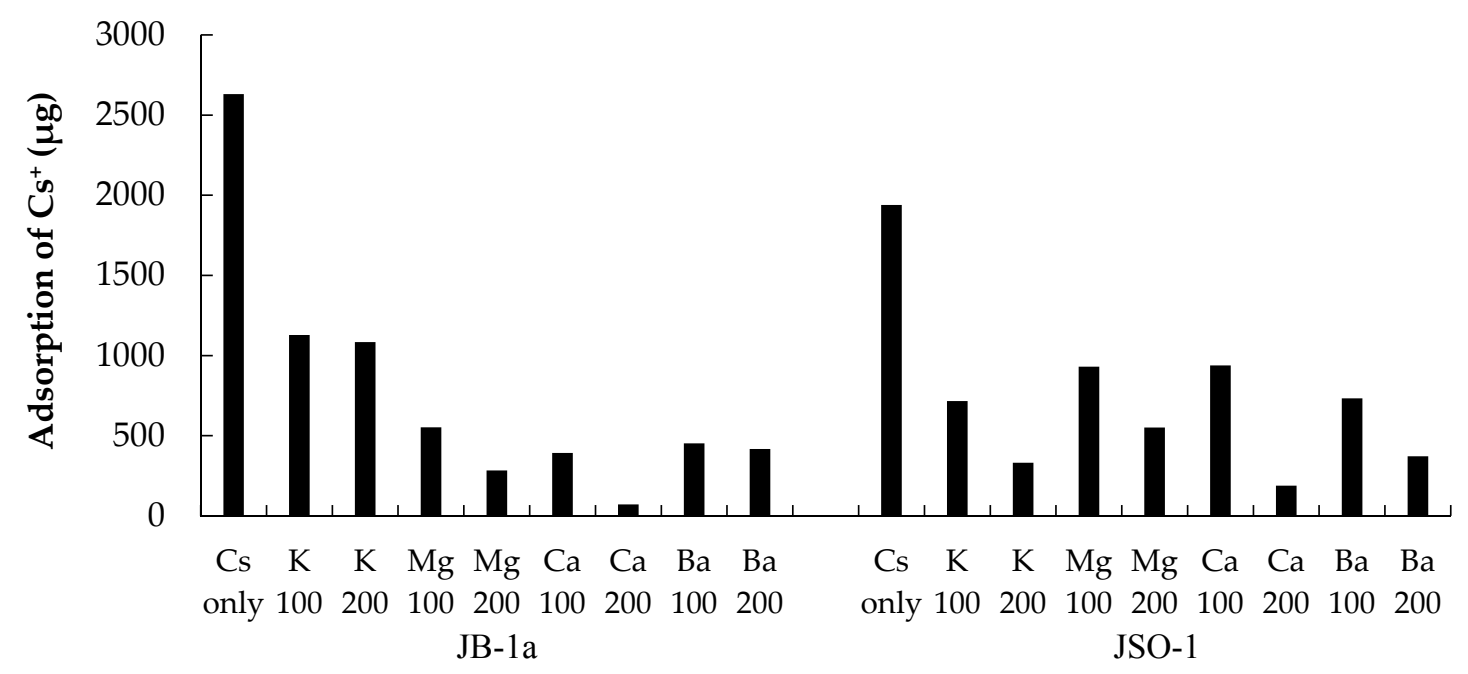

Figure 4. Adsorption quantity for $\mathrm{Cs}^{+}$in solutions with coexisting ions: $\mathrm{K}^{+}, \mathrm{Mg}^{2+}, \mathrm{Ca}^{2+}$, and $\mathrm{Ba}^{2+}$. The initial concentration of each coexisting ion was 100 or $200 \mathrm{mg} / \mathrm{L}$.

\subsection{Adsorption Quantity of $\mathrm{Cs}^{+}$for $\mathrm{pH}$ Change}

The adsorption quantity of $\mathrm{Cs}^{+}$onto JB-1a and JSO-1 increased with increasing $\mathrm{pH}$ (Figure 5). In particular, the adsorption of $\mathrm{Cs}^{+}$onto JSO-1 increased approximately 2.7-fold as the conditions were adjusted from neutral to basic. The adsorption quantity of $\mathrm{Cs}^{+}$onto JSO-1 fluctuated dramatically when large quantities of corrosion products were present. The corrosion products include soil organic materials that exhibit a negative surface charge under basic $\mathrm{pH}$ conditions in aqueous solution $[23,24]$. Therefore, the quantity of adsorbed $\mathrm{Cs}^{+}$on JSO increased with increasing $\mathrm{pH}$.

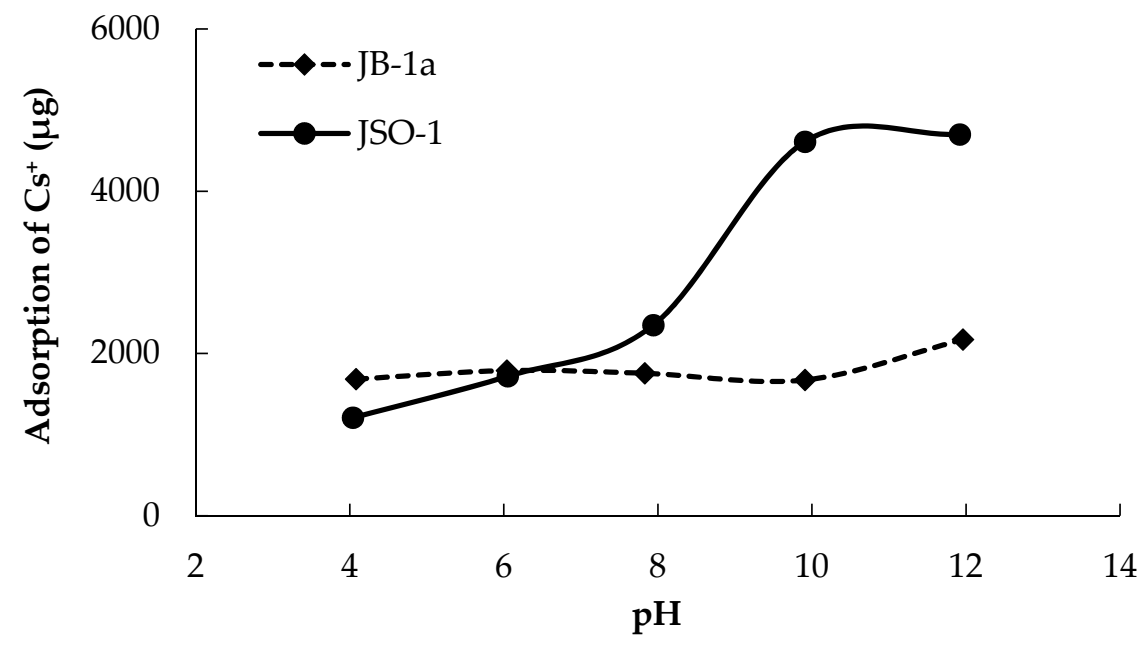

Figure 5. Effect of $\mathrm{pH}$ on the adsorption quantity for $\mathrm{Cs}^{+}$onto JB-1a and JSO-1 $(0.5 \mathrm{~g})$. Initial $\mathrm{Cs}^{+}$ concentration: $200 \mathrm{mg} / \mathrm{L}$.

\subsection{Desorption of $\mathrm{Cs}^{+}$from Natural Japanese Rocks}

Figure 6 shows that desorption of $\mathrm{Cs}^{+}$varied with the type of salt and that the desorption ratio was highest in the case of ammonium salts. The ionic radius of exchangeable cations increases in the order $\mathrm{Ca}^{2+}<\mathrm{Na}^{+}<\mathrm{K}^{+}<\mathrm{NH}_{4}{ }^{+}<\mathrm{Cs}^{+}[25,26]$. The experimental results are likely attributable to a strong chemical attraction among $\mathrm{NH}_{4}{ }^{+}$ions, whose ionic radii are essentially equal to those of $\mathrm{Cs}^{+}$ions. In addition, the desorption ratio of $\mathrm{Cs}^{+}$in the presence of EDTA was approximately $80 \%$, which is attributed to the ion-coordinating ability of EDTA and the ion-exchange ability of 
$\mathrm{Na}^{+}$. Structure components, such as $\mathrm{Al}^{3+}$ in JB-1a, can be dissolved by hydrochloric acid [10]. In this study, $\mathrm{Cs}^{+}$was easily desorbed from rock samples in $\mathrm{H}_{2} \mathrm{O}$ (desorption ratio $30 \%$ ) and in hydrochloric acid (desorption ratio 80\%), due to the intentionally high concentrations of $\mathrm{Cs}^{+}$adsorbed onto the rock samples.

The desorption of $\mathrm{Cs}^{+}$ions was reported to be difficult under conditions where the adsorbed quantity for $\mathrm{Cs}^{+}$onto the substrate was low, as is true for natural soil [20,21]. In this work, however, we observed that high desorption ratios of $\mathrm{Cs}^{+}$were due to the large adsorbed quantity of $\mathrm{Cs}^{+}$.

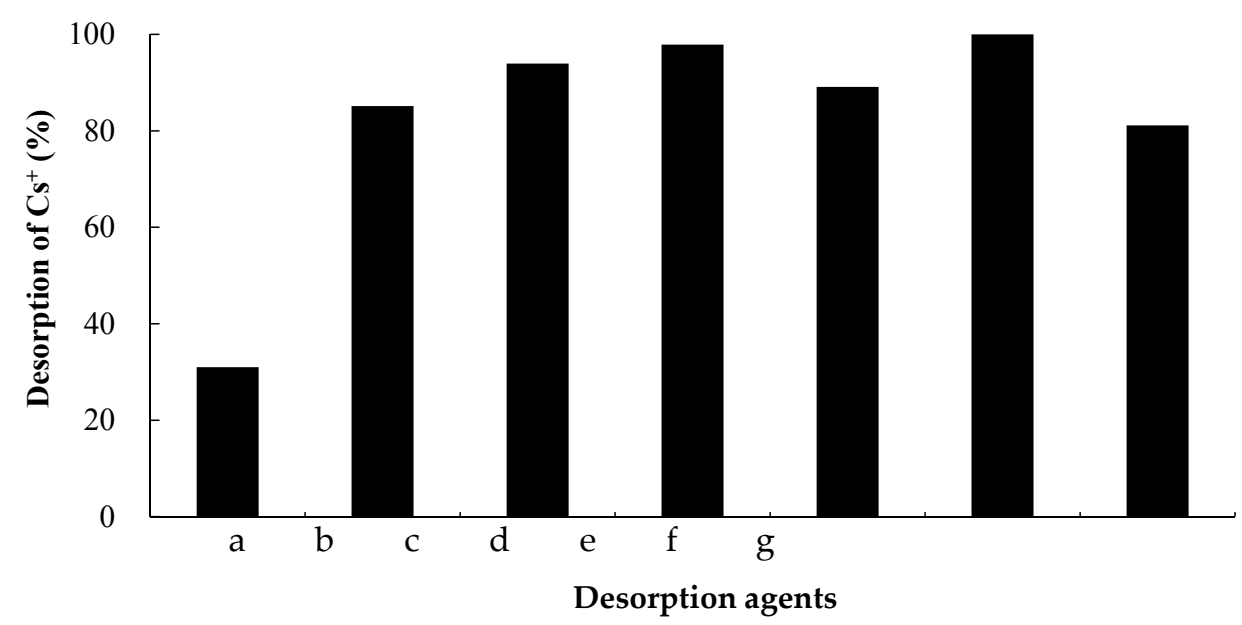

Figure 6. Desorption ratio (\%) of $\mathrm{Cs}^{+}$from JB-1a (0.5 g) using $0.1 \mathrm{~mol} / \mathrm{L}$ solutions of different salts. a: $\mathrm{H}_{2} \mathrm{O}, \mathrm{b}: \mathrm{HCl}$, c: $\left(\mathrm{NH}_{4}\right)_{2} \mathrm{HPO}, \mathrm{d}: \mathrm{NH}_{4} \mathrm{Cl}$, e: $\mathrm{NH}_{4} \mathrm{~F}$, f: $\left(\mathrm{NH}_{4}\right)_{2} \mathrm{C}_{2} \mathrm{O}_{4}$, and g: Ethylenediaminetetraacetic acid disodium salt, 2-hydrate. The desorption ratios were calculated based on the $\mathrm{Cs}^{+}$adsorption quantities in Figure 2.

\subsection{Desorption of $\mathrm{Cs}^{+}$with Coexisting Ions}

Figure 7 shows that the $\mathrm{Cs}^{+}$desorption ratio in the presence of other coexisting ions differed depending on the type of rock. We confirmed that desorption of $\mathrm{Cs}^{+}$from JB-1a using monovalent cations such as $\mathrm{K}^{+}$was easier than the desorption using divalent cations. Desorption from JSO- 1 was more strongly influenced by $\mathrm{Ba}^{2+}$ due to the ionic radius of $\mathrm{Ba}^{2+}$ being similar to that of cesium [27]. We confirmed that $\mathrm{K}^{+}$most strongly promoted $\mathrm{Cs}^{+}$desorption from JSO-1 and JB-1a, respectively, in the presence of coexisting cations.

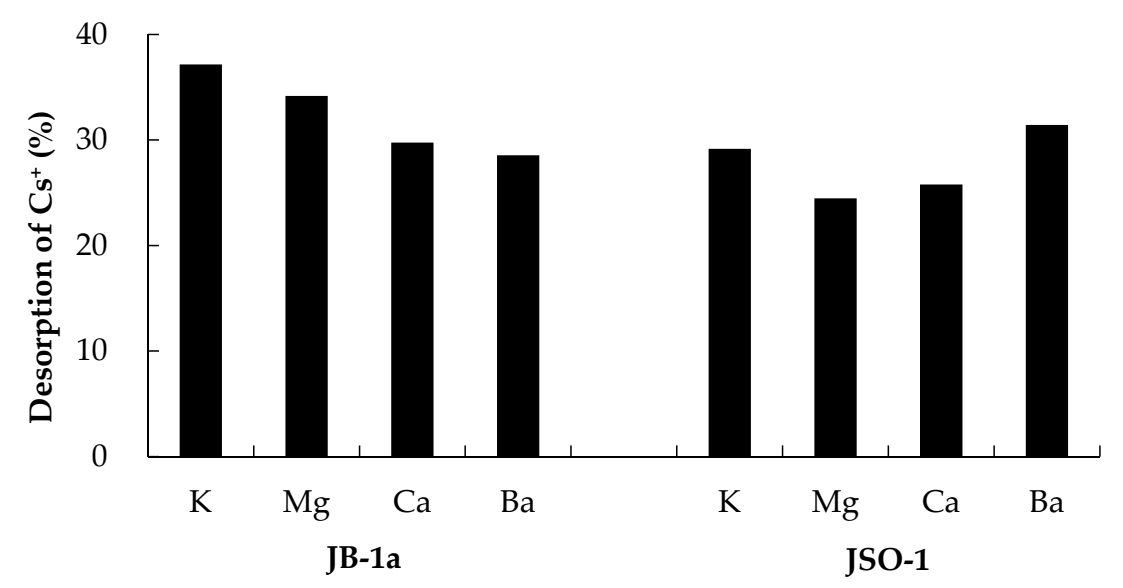

Figure 7. Desorption ratio (\%) of $\mathrm{Cs}^{+}$from JB-1a and JSO-1 $(0.5 \mathrm{~g})$ in solutions with coexisting ions (initial concentration: $200 \mathrm{mg} / \mathrm{L}$ ); the desorption ratios were calculated based on the $\mathrm{Cs}^{+}$adsorption quantities in the absence of the coexisting ions (Figure 2). 


\subsection{Effect of the Heat Treatment of Rocks}

Table 2 shows the influence of calcination temperature on the adsorption of $\mathrm{Cs}^{+}$onto the rock samples. The adsorption quantity for $\mathrm{Cs}^{+}$onto all rocks decreased with increasing calcination temperature. The adsorption quantity of $\mathrm{Cs}^{+}$onto rocks calcined at $1000{ }^{\circ} \mathrm{C}$ was limited to approximately $20 \%$ or less of the saturated adsorbent quantities in the absence of calcination. The adsorption quantities of $\mathrm{Cs}^{+}$onto all rocks calcined at $1100{ }^{\circ} \mathrm{C}$ were below the lower detection limit of the ICP-MS instrumentation.

Table 2. Adsorption ratio (\%) for $\mathrm{Cs}^{+}$onto rocks $(0.5 \mathrm{~g})$ calcined at various temperatures, as calculated based on the $\mathrm{Cs}^{+}$adsorption quantities without calcination (Figure 2).

\begin{tabular}{cccccc}
\hline & $\mathbf{4 0 0}{ }^{\circ} \mathbf{C}$ & $\mathbf{6 0 0}{ }^{\circ} \mathbf{C}$ & $\mathbf{8 0 0}{ }^{\circ} \mathbf{C}$ & $\mathbf{1 0 0 0}{ }^{\circ} \mathbf{C}$ & $\mathbf{1 1 0 0}{ }^{\circ} \mathbf{C}$ \\
\hline JB & 68.1 & 58.3 & 28.6 & 19.8 & 0.0 \\
JSO & 98.5 & 76.7 & 45.1 & 17.5 & 0.0 \\
JA & 35.8 & 24.5 & 26.4 & 14.2 & 0.0 \\
JSd & 100 & 30.0 & 13.6 & 0.0 & 0.0 \\
JS1 & 90.2 & 83.4 & 48.0 & 21.2 & 0.0 \\
\hline
\end{tabular}

Dehydration, oxidation decomposition, oxidation, and melting events for each rock sample were detected by TG-DTA (Figure 8). These results indicate that structural changes, such as melting and decomposition, occur during heating, leading to a reduction in the soil interlayer distance by dehydration.

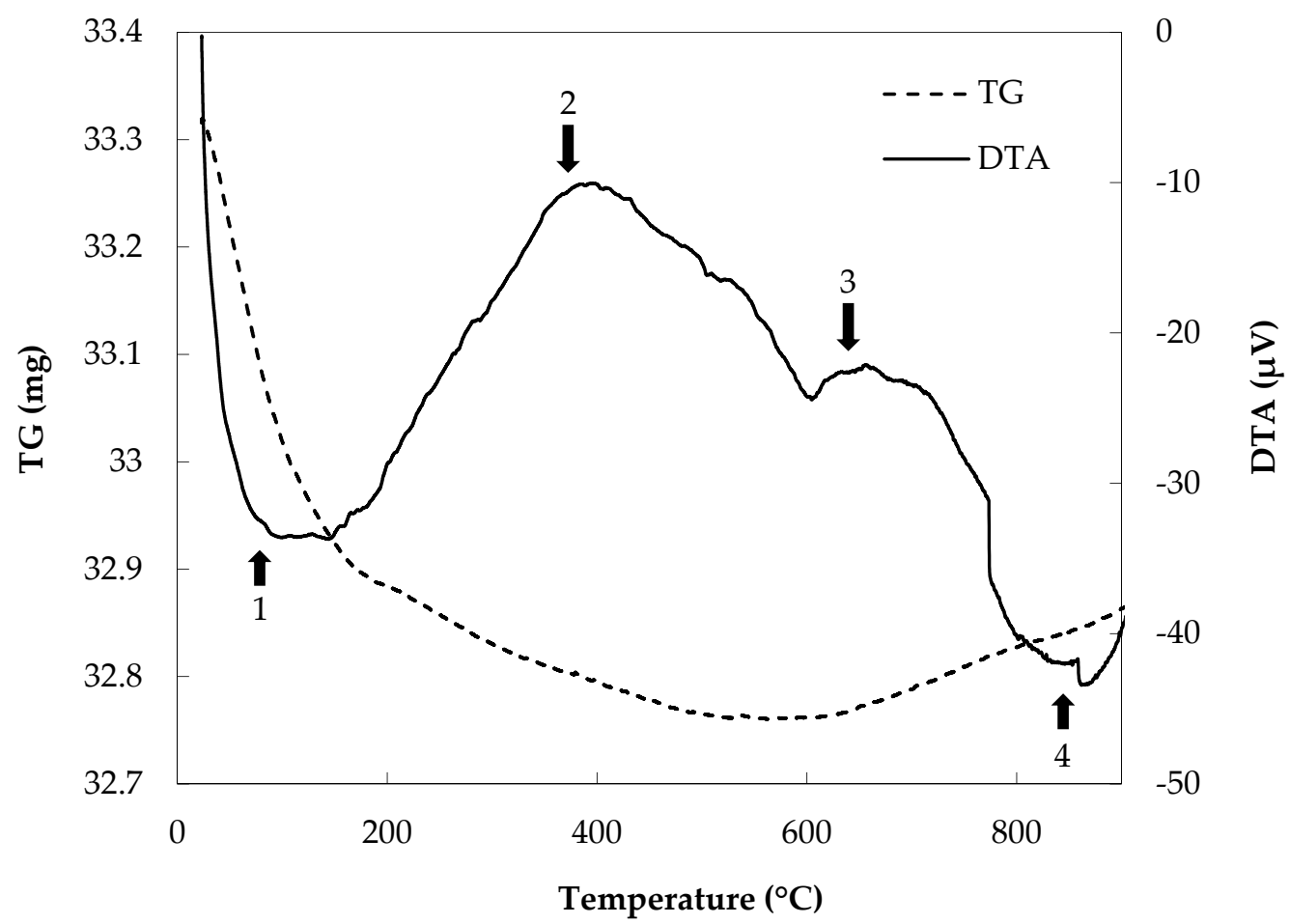

Figure 8. Thermogravimetric and differential analysis (TG-DTA) patterns for JB-1a: 1. dehydration, 2. oxidation decomposition, 3. oxidation, and 4. melting.

In addition, Figure 9 shows the XRD patterns for rock samples calcined at different temperatures. The diffraction peaks of the rock samples decreased in intensity with increasing calcination temperature. These results indicate that the skeleton structure of the rocks was destroyed by heat. 


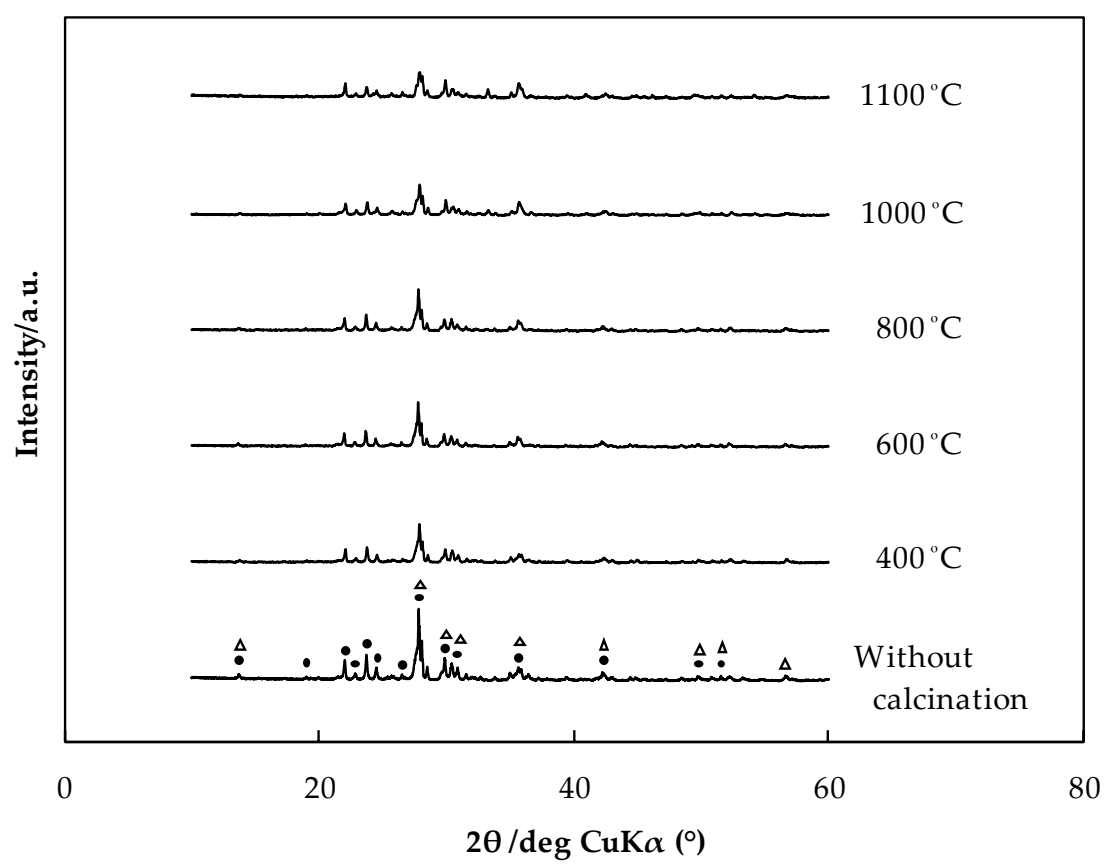

Figure 9. X-ray diffraction (XRD) patterns of JB-1a calcined at various temperatures ( $\bullet$ : albite calcian; $\triangle$ : augite; $\mathrm{CuK} \alpha$; scan rate: $10^{\circ} / \mathrm{min}$; and step scan size: $0.02^{\circ}$ ).

The effects of melting of the surfaces of the rock samples were observed by SEM (Figure 10). The surfaces of rocks not subjected to calcination were uneven, as shown in Figure 10a,c. The surface structure of the rocks calcined at $1000{ }^{\circ} \mathrm{C}$ became smooth. All rock samples were changing state due to heat. Therefore, the adsorption of $\mathrm{Cs}^{+}$onto the rocks was inhibited by a decrease in the number of adsorption sites upon heat treatment.

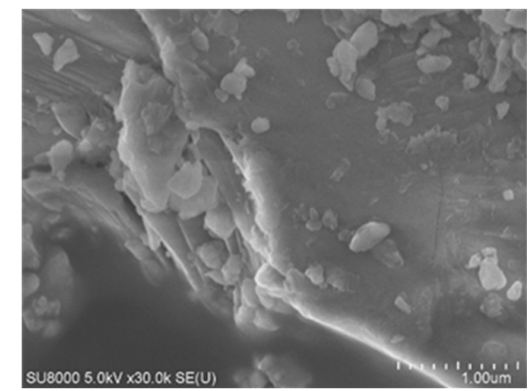

(a)

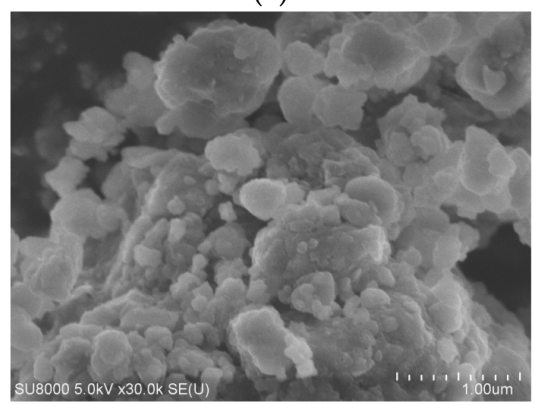

(c)

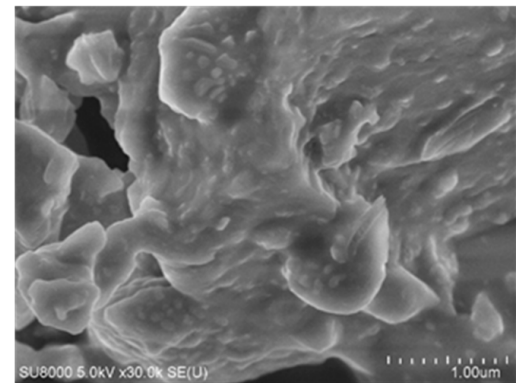

(b)

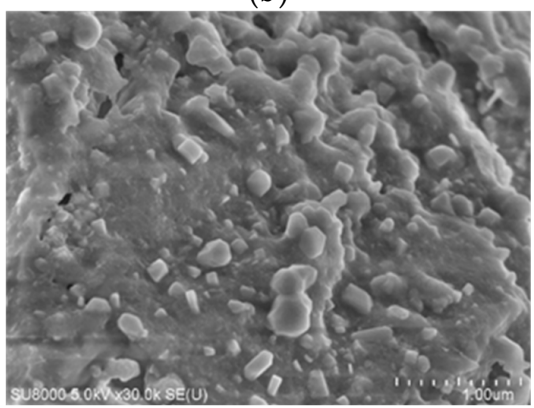

(d)

Figure 10. Scanning electron microscopy (SEM) images of (a) JB-1a and (c) JSO-1 without calcination and (b) JB-1a and (d) JSO-1 after calcination at $1000{ }^{\circ} \mathrm{C}$; magnification: 30,000 $\times$. 
Table 3 shows that the desorption quantity of $\mathrm{Cs}^{+}$from rocks tended to decrease with increasing calcination temperature. This result is related to changes in the skeletal structure and the $\mathrm{Cs}^{+}$adsorption behavior. The desorption of $\mathrm{Cs}^{+}$from, for example, soil interlayers and pores, would be inhibited by the melting rock surface. In particular, the inhibitory effect of $\mathrm{Cs}^{+}$desorption was high in cases where the rock was calcined at temperatures greater than at $1000{ }^{\circ} \mathrm{C}$. Nevertheless, $\mathrm{Cs}^{+}$desorption from rock samples calcined at 400 and $600{ }^{\circ} \mathrm{C}$ occurred easily due to incomplete structural changes and because the cations were not trapped inside the rock. Consequently, heat treatments, similar to the calcination at $1000{ }^{\circ} \mathrm{C}$ described above, are expected to be used as the final disposal method for contaminated soil.

Table 3. Desorption ratio (wt \%) of $\mathrm{Cs}^{+}$from the rocks $(0.5 \mathrm{~g})$ calcined at various temperatures, as calculated based on the $\mathrm{Cs}^{+}$adsorption quantities $\mathrm{t}$ without calcination (Figure 2).

\begin{tabular}{cccccccccccc}
\hline & \multicolumn{3}{c}{ Water } & \multicolumn{4}{c}{ HCl (pH 1) } \\
\hline $\left.\mathbf{(}^{\circ} \mathbf{C}\right)$ & Non calcination & $\mathbf{4 0 0}$ & $\mathbf{6 0 0}$ & $\mathbf{8 0 0}$ & $\mathbf{1 0 0 0}$ & $\mathbf{1 1 0 0}$ & $\mathbf{4 0 0}$ & $\mathbf{6 0 0}$ & $\mathbf{8 0 0}$ & $\mathbf{1 0 0 0}$ & $\mathbf{1 1 0 0}$ \\
\hline JB & 31.0 & 3.4 & 2.2 & 0.6 & 0.2 & 0.2 & 87.1 & 47.1 & 4.8 & 1.4 & 0.2 \\
JSO & 39.2 & 11.2 & 13.0 & 5.9 & 0.5 & 0.8 & 88.6 & 50.2 & 23.8 & 2.6 & 1.5 \\
JA & 31.0 & 10.2 & 8.8 & 4.2 & 2.3 & 0.9 & 58.4 & 31.1 & 16.6 & 3.8 & 0.3 \\
JSd & 90.1 & 31.6 & 15.1 & 9.9 & 3.0 & 1.3 & 95.9 & 52.0 & 16.1 & 4.3 & 0.8 \\
JSl & 65.5 & 29.3 & 16.7 & 15.5 & 1.1 & 0.5 & 100 & 100 & 35.2 & 2.2 & 0.4 \\
\hline
\end{tabular}

\section{Conclusions}

We confirmed that $\mathrm{Cs}^{+}$adsorption onto volcanic rocks $(0.9-5.3 \mathrm{mg} / \mathrm{g}$ ) occurred more easily than that onto plutonic rocks $(0.7-0.8 \mathrm{mg} / \mathrm{g})$. Adsorption quantity of $\mathrm{Cs}^{+}$onto rock samples increased with increasing exchangeable cation quantity in the solution and decreasing rock crystallinity. Cesium adsorption quantities for the before weathering rocks were higher than for the after weathering rocks. The adsorption quantity for $\mathrm{Cs}^{+}$onto all the rock samples decreased when seawater was used. The adsorption of $\mathrm{Cs}^{+}$was inhibited under adsorption experiments conducted with $\mathrm{Ca}^{2+}$ ions coexisting in the solution. In addition, the adsorption quantity of $\mathrm{Cs}^{+}$onto JSO increased approximately 2.7-fold when the solution $\mathrm{pH}$ was changed from acidic to basic. We determined that the adsorption behavior in the case of JSO-1 was influenced by the $\mathrm{pH}$-dependency of the corrosion product.

The desorption ratio of $\mathrm{Cs}^{+}$in the case of ion exchange with $\mathrm{NH}_{4}{ }^{+}$salts was relativity high. The ionic radius of exchangeable cations occurs in the increasing order: $\mathrm{Ca}^{2+}<\mathrm{Na}^{+}<\mathrm{K}^{+}<\mathrm{NH}_{4}^{+}<\mathrm{Cs}^{+}$. Cesium desorption behavior with ammonium salts was attributable to a strong chemical attraction among $\mathrm{NH}_{4}{ }^{+}$, whose ionic radius is substantially equal to that of a $\mathrm{Cs}^{+}$ion. Desorption behavior with coexisting ions was related to the valence and radius of the ions.

The quantity of $\mathrm{Cs}^{+}$adsorbed onto and desorbed from all the rock samples decreased with increasing rock calcination temperature. The results were influenced by the melting of the rock surface, which decreased the number of available adsorption sites.

In this study, we confirmed that the cesium adsorption and desorption characteristics were changed by the major constituent elements in the natural Japanese rocks and the condition of the reaction solution (seawater, coexisting ions, and $\mathrm{pH}$ ). These characteristics of rock in natural environments are influenced by many factors, such as structure, weathering condition, exchangeable cations, and $\mathrm{pH}$. This research result, using natural Japanese rocks with well-known components, is expected to help elucidate and simplify the cesium adsorption/desorption characteristics for contaminated soil. Additionally, we were able to control the cesium adsorption and desorption with the calcination of rocks. 
Author Contributions: Conceptualization, T.M.; M.E.; Data Curation, T.M.; A.S.; M.E.; Formal Analysis, T.M.; A.S.; M.E.; Investigation, T.M.; Methodology, T.M.; A.S.; M.E.; Project Administration, T.M.; M.E; Supervision, M.E.; Validation, A.S.; M.E.; Writing Original Draft Preparation, T.M.; Writing Review and Editing, A.S.; M.E; All authors have read and approved the final manuscript. Atsushi Sasaki is my adviser for the experiment and writing article. Masatoshi Endo is my PhD supervisor.

Funding: This research received the funding from Japan Society of Ion Exchange.

Conflicts of Interest: The authors declare no conflicts of interest.

\section{References}

1. Fujii, K.; Ikeda, S.; Akama, A.; Komatsu, M.; Takahashi, M.; Kaneko, S. Vertical migration of radiocesium and clay mineral composition in five forest soils contaminated by the Fukushima nuclear accident. Soil Sci. Plant Nutr. 2014, 60, 751-764. [CrossRef]

2. Parajuli, D.; Takahashi, A.; Tanaka, H.; Sato, M.; Fukuda, S.; Kamimura, R.; Kawamoto, T. Variation in available cesium concentration with parameters during temperature induced extraction of cesium from soil. J. Environ. Radioact. 2015, 140, 78-83. [CrossRef] [PubMed]

3. Mukai, H.; Hirose, A.; Motai, S.; Kikuchi, R.; Tanoi, K.; Nakanishi, T.; Yaita, T.; Kogure, T. Cesium adsorption/desorption behavior of clay minerals considering actual contamination conditions in Fukushima. Sci. Rep. 2016, 6, 21543. [CrossRef] [PubMed]

4. Kogure, T.; Morimoto, K.; Tamura, K.; Sato, H.; Yamagishi, A. XRD and HRTEM Evidence for Fixation of Cesium Ions in Vermiculite Clay. Chem. Lett. 2012, 41, 380-382. [CrossRef]

5. Benedicto, A.; Missana, T.; Fernández, A.M. Interlayer collapse affects on cesium adsorption onto illite. Environ. Sci. Technol. 2014, 48, 4909-4915. [CrossRef] [PubMed]

6. Zaunbrecher, L.K.; Cygan, R.T.; Elliott, W.C. Molecular models of cesium and rubidium adsorption on weathered micaceous minerals. J. Phys. Chem. A 2015, 119, 5691-5700. [CrossRef] [PubMed]

7. Fuller, A.J.; Shaw, S.; Peacock, C.L.; Trivedi, D.; Small, J.S.; Abrahamsen, L.G.; Burke, I.T. Ionic strength and $\mathrm{pH}$ dependent multi-site sorption of Cs onto a micaceous aquifer sediment. Appl. Geochem. 2014, 40, 32-42. [CrossRef]

8. Endo, M.; Yoshikawa, E.; Muramatsu, N.; Takizawa, N.; Kawai, T.; Unuma, H.; Sasaki, A.; Masano, A.; Takeyama, Y.; Kahara, T. The removal of cesium ion with natural Itaya zeolite and the ion exchange characteristics. J. Chem. Technol. Biotechnol. 2013, 88, 1597-1602. [CrossRef]

9. Chiang, P.N.; Wang, M.K.; Huang, P.M.; Wang, J.J. Effects of low molecular weight organic acids on (137) Cs release from contaminated soils. Appl. Radiat. Isot. 2011, 69, 844-851. [CrossRef] [PubMed]

10. Miura, T.; Takizawa, N.; Togashi, K.; Sasaki, A.; Endo, M. Adsorption/Desorption Characteristics of Cesium Ions on Natural and Synthetic Minerals. J. Ion Exch. 2018, 29, 9-15. [CrossRef]

11. Osuna, F.J.; Cota, A.; Pavón, E.; Pazos, M.C.; Alba, M.D. Cesium adsorption isotherm on swelling high-charged micas from aqueous solutions: Effect of temperature. Am. Mineral. 2018, 103, 623-628. [CrossRef]

12. Durrant, C.B.; Begg, J.D.; Kersting, A.B.; Zavarin, M. Cesium sorption reversibility and kinetics on illite, montmorillonite, and kaolinite. Sci. Total Environ. 2018, 610, 511-520. [CrossRef] [PubMed]

13. Jiang, M.Q.; Jin, X.Y.; Lu, X.Q.; Chen, Z.L. Adsorption of Pb(II), Cd(II), Ni(II) and Cu(II) onto natural kaolinite clay. Desalination 2010, 252, 33-39. [CrossRef]

14. Bostick, B.C.; Vairavamurthy, M.A.; Karthikeyan, K.G.; Chorover, J. Cesium adsorption on clay minerals: An EXAFS spectroscopic investigation. Environ. Sci. Technol. 2002, 36, 2670-2676. [CrossRef] [PubMed]

15. Nakao, A.; Thiry, Y.; Funakawa, S.; Kosaki, T. Characterization of the frayed edge site of micaceous minerals in soil clays influenced by different pedogenetic conditions in Japan and northern Thailand. Soil Sci. Plant Nutr. 2008, 54, 479-489. [CrossRef]

16. GSJ Geochemical Reference Samples Data Base. Available online: https://gbank.gsj.jp/geostandards / welcome.html (accessed on 14 June 2018).

17. Johnson, W.M.; Maxwell, J.A. Rock and Mineral Analysis, 2nd ed.; John Wiley \& Sons: New York, NY, USA, 1981; ISBN 139780471027430.

18. Miura, K. Weathering during late Pliocene of Gotsu plutonic rocks. J. Jpn. Soc. Eng. Geol. 1973, 14, 87-102. [CrossRef] 
19. Onikata, M.; Kondo, M.; Hayashi, N.; Yamanaka, S. Complex formation of cation-exchanged montmorillo-nites with propylene carbonate: Osmotic swelling in aqueous electrolyte solutions. Clays Clay Miner. 1999, 47, 672-677. [CrossRef]

20. Morimoto, K.; Kogure, K.; Tamura, K.; Tomofuji, T.; Yamagishi, A.; Sato, H. Desorption of Cs ${ }^{+}$Ions Intercalated in Vermiculite Clay through Cation Exchange with $\mathrm{Mg}^{2+}$ Ions. Chem. Lett. 2012, 41, 1715-1717. [CrossRef]

21. Tamura, K.; Sato, H.; Yamagishi, A. Desorption of $\mathrm{Cs}^{+}$ions from a vermiculite by exchanging with $\mathrm{Mg}^{2+}$ ions: Effects of $\mathrm{Cs}^{+}$-capturing ligand. J. Radioanal. Nucl. Chem. 2015, 303, 2205-2210. [CrossRef]

22. Dzene, L.; Tertre, E.; Hubert, F.; Ferrage, E. Nature of the sites involved in the process of cesium desorption from vermiculite. J. Colloid Interface Sci. 2015, 455, 254-260. [CrossRef] [PubMed]

23. Komy, Z.R.; Shaker, A.M.; Heggy, S.E.M.; El-Sayed, M.E.A. Kinetic study for copper adsorption onto soil minerals in the absence and presence of humic acid. Chemosphere 2014, 99, 117-124. [CrossRef] [PubMed]

24. Dumat, C.; Stauton, S. Reduced adsorption of caesium on clay minerals caused by various humic substances. J. Environ. Radioact. 1999, 46, 187-200. [CrossRef]

25. Brouwer, E.; Baeyens, B.; Maes, A.; Cremers, A. Cesium and rubidium ion equilibriums in illite clay. J. Phys. Chem. 1983, 87, 1213-1219. [CrossRef]

26. Staunton, S.; Roubaud, M. Adsorption of $137 \mathrm{Cs}$ on montmorillonite and illite: Effect of charge compensating cation, ionic strength, concentration of Cs, K, and fluvic acid. Clays Clay Miner. 1997, 45, 251-260. [CrossRef]

27. Environmental Chemistry.com. Available online: https://environmentalchemistry.com/yogi/periodic/ionicradius.html (accessed on 14 June 2018).

(C) 2018 by the authors. Licensee MDPI, Basel, Switzerland. This article is an open access article distributed under the terms and conditions of the Creative Commons Attribution (CC BY) license (http://creativecommons.org/licenses/by/4.0/). 